\title{
Investigation of Laser Welding Technology of Diamond Drilling Segments
}

\author{
Attila Zsolt KENÉZ, ${ }^{1,2}$ Gyula BAGYINSZKI ${ }^{3}$ \\ ${ }^{1}$ Hilti Tools Ltd., Kecskemét, Hungary, attila.kenez@hilti.com \\ ${ }^{2}$ Óbuda University, Doctoral School on Materials Sciences and Technologies, Budapest, Hungary, \\ kenez.attila@phd.uni-obuda.hu \\ ${ }^{3}$ Óbuda EUniversity, Donát Bánki Faculty of Mechanical and Safety Engineering, Budapest, Hungary, \\ bagyinszki.gyula@bgk.uni-obuda.hu
}

\begin{abstract}
Segments containing diamond particles are fixed to replaceable inserts or to steel tool bodies for cost-effectiveness. The joining technology used should meet both environmental and technical requirements. The joining zone is subjected to high mechanical and significant thermal loads during use. In the event of an improper joint, the segments may detach from the base and fly away causing injury. Nowadays, many methods of welding or brazing are used to fix diamond segments. Among the possible segment fixing technologies, laser beam welding has been investigated. The microstructure of the joints has been examined by optical and scanning electron microscopy and chemical element maps have been recorded. Joints have been subjected to fracture and hardness testing. The mechanical properties and composition changes of the joints with different joining technologies have been evaluated and compared.
\end{abstract}

Keywords: joining technologies, welding, diamond segment, material testing

\section{Introduction}

There has been an increased demand from the construction industry for the planned or improvised on-site machining of concrete, requiring tools with a typical application in the areas of chiselling, drilling, wall opening, channelling or surface roughening. These are performed effectively with diamond-edged tools.

At Hilti Tools Ltd. core drill bits with diamond segments [1] are manufactured for a wide range of applications, raw materials and with different performance requirements. The segments are laser welded on the thin walled tube of the core drill bit. In the case of the core bits (diameter range: $\emptyset 8 . .37 \mathrm{~mm}$ ), a $\mathrm{CO}_{2}$ laser source is used, while in the case of drill bits (diameter range: $\emptyset 40 \ldots 202$ $\mathrm{mm}$ ) a disk laser source is used for welding.

\section{Laser welding}

In the small diameter focus spot a very high power density can be achieved, and by absorption, the electromagnetic radiation is transformed into heat in the materials being welded. In a narrow band the heat melts the boundary of the joined pieces and behind the passing radiation a narrow heat-effect, little distortion seam is formed. [2]

Gas laser welding is usually performed with 10,6 $\mu$ mwavelength (far-infrared) radiation $\mathrm{CO}_{2}+\mathrm{N}_{2}+\mathrm{He}$ gas mixture. In this case, $\mathrm{CO}_{2}$ gas gives rise to the laser's name. [3]

Disc laser welding, e.g. 1,03 $\mu \mathrm{m}$ wavelength (close infrared) radiation, can be achieved by Yb: YAG or Nd:YAG lasers. The Yttrium-aluminium-garnet crystal (YAG) refers to the solid state laser. These lasers have better efficiency compared to $\mathrm{CO}_{2}$ lasers. [4] [5] 


\section{Inspections, results}

The welded core bits and drill bits have to fulfil their technical requirements. First, we performed non-destructive and destructive tests used in serial production, then the welded bond and the heat affected zone were investigated in more detail.

\subsection{Test methods}

The non-destructive tests in serial production were as follows:

- Optical inspection: visual inspection of the seam; -Segment offset (device: dial gauge): the segments have to be positioned on a diameter larger than the outer diameter of the tube;

-segment tilt (device: dial gauge): the parallelism of the segments on the lateral surface of the tube;

-segment twist (device: dial gauge): the difference between the radius of the segment and the radius of the tube;

- radial run out (device: dial gauge): radial run out measured on the surface of the segment while rotating the core drill bit.

Destructive tests used in serial production:

- breakage test (device: digital torque wrench) an insert (in a fitting shape), which is connected to the torque wrench is put on the segment of the product to be examined. After resetting the wrench the segment is broken off and the displayed value read, which has been converted into the position of the breakage.

The welded bond and its environment are examined by the following methods:

- optical light microscope inspection;

-Scanning Electron Microscope, SEM inspection;

- Energy Dispersive Spectroscopy (EDS);

-Hardness measurement with Vickers method.

\subsection{Inspection results}

Based on the optical microscope investigation the following can be concluded:

- the geometry of the examined samples' welding seam (Figure 1. and 2.) is similar;

- gas inclusions (Figure 3.) occur in the welding seams.

After the performed SEM investigation the following can be concluded:

-in some cases crack-like patterns can be observed (Figure 4.);

-in the case of C, Mn, Si no significant difference can be seen between the specific zones (Figure 5.); -although from the neutral zones nickel is alloyed into the seam (Figure 6.).

In the course of the line analysis, we scanned the specimen along a line with the electron beam (Figure 7.).

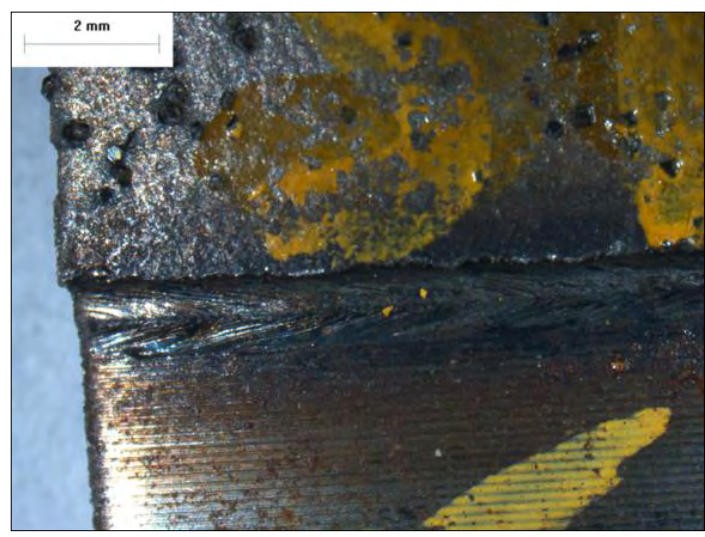

Figure 1. Stereo microscope recording of the laser welded seam from the crown side

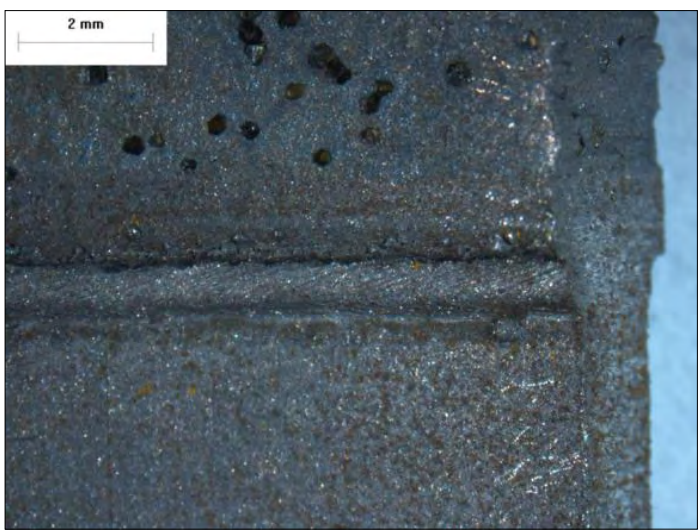

Figure 2. Stereo microscope recording of the laser welded seam from the root side

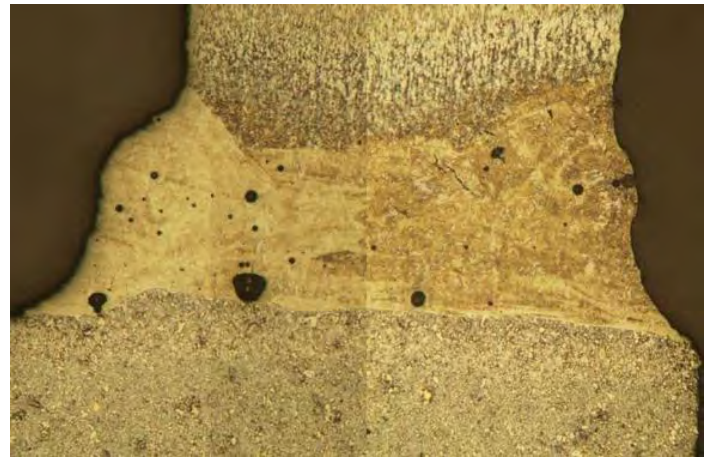

Figure 3. Optical microscope recording of the laser welded seam 


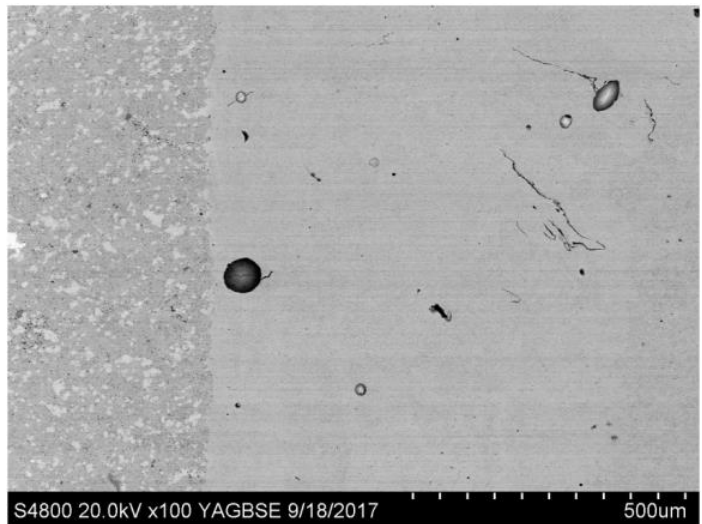

Figure 4. SEM recording from the middle zone of the laser welded bond
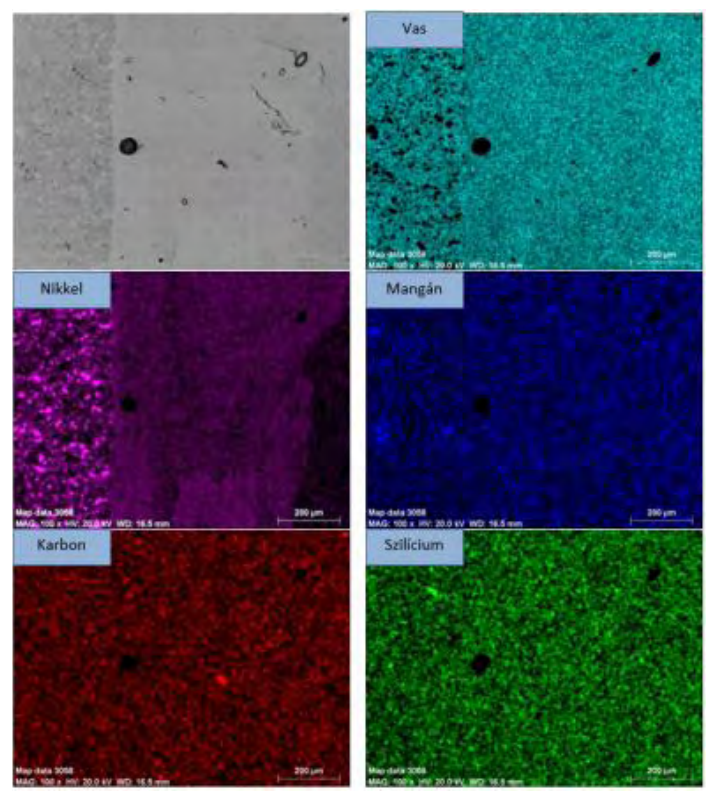

Figure 5. Element map from the middle zone of the laser welded bond

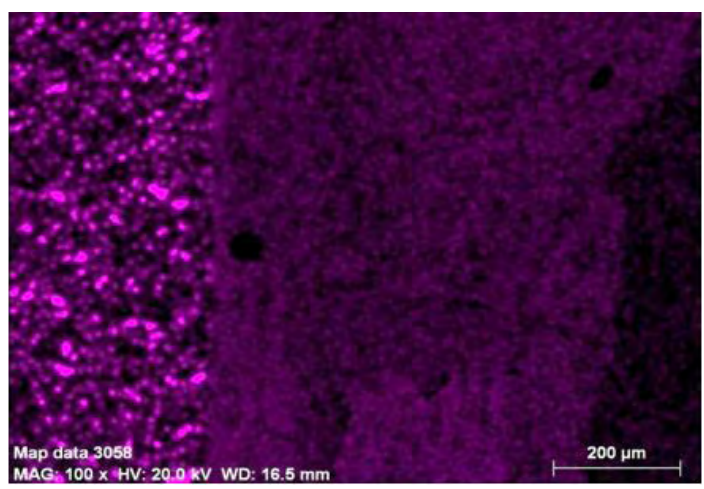

Figure 6. Ni element map from the middle zone of the laser welded bond

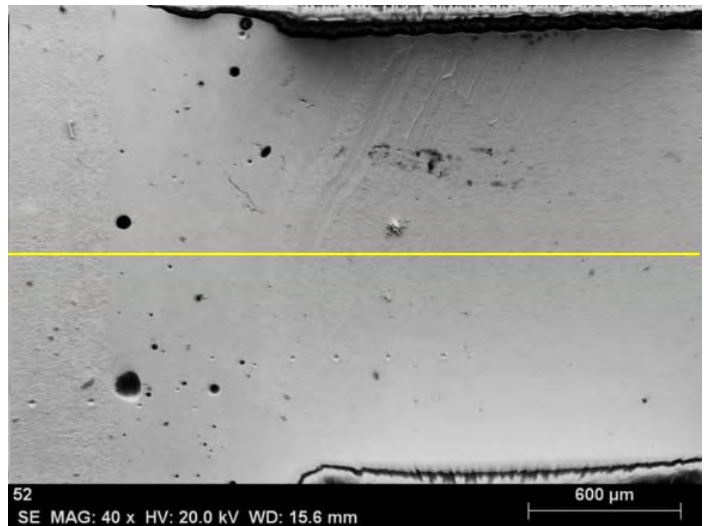

Figure 7. SEM recording of laser welded bond, the thin yellow line indicates the place of the line analysis (close to the root)

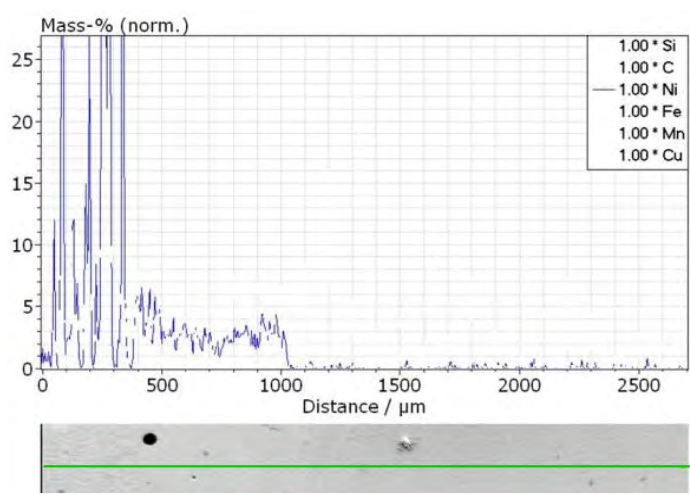

Figure 8. Laser welded bond's nickel concentration perpendicular to the seam's line in the middle of the seam

The Energy Dispersive Spectroscopy (EDX) gathers the different energy level X-ray photons (this will be the EDX spectrum) and along the line, for every point, the measured EDX spectrum is assigned.

The concentration of the nickel atom is proportional to the energy level count of the nickel atoms on the EDX spectrum. Changing the electron beam can cause changes in the energy level count, so in the case of two or more fields of view the counts cannot be compared.

Due to this, we determined the specimen's raw material and alloying elements with a full territorial analysis. During the line analysis each element count has been recorded and after normalization, to $100 \%$ we derived the nickel (and all the other elements') true percentage by mass.

In Figure 8. only the distribution of nickel can be seen. The start of the line analysis always starts 
from the powder metallurgy raw material, where nickel particles can be seen as well, thus, at the beginning of the analysis peaks can be seen reaching almost $100 \%$ (the top of the peaks cannot be seen), but the vertical scale's maximum has been set to $25 \%$ so the low concentration nickel in the seam can be also read from the diagram.

\section{Consequences}

The presented recordings and the inspection results demonstrate the chosen and applied methods of the research.

It can conclude, the applied experimental methods are able to inspect the laser welded and by other type joints, and it can extend by other material tests (like hardness tests).

\section{References}

[1] Vincent C.: Apparatus and Method for Securing Diamond Segment to Rotating Tool. US 2005/0279533 A1, 2005.

[2] Bagyinszki Gy., Bitay E.: Hegesztéstechnika I. Eljárások és gépesítés. EME, Cluj-Napoca, 2010. https://eda.eme.ro/handle/10598/15437

[3] Kovács T.: Laser welding process specification base on welding theories. Procedia Manufacturing, 22. (2018) 147-153.

[4] Bitay E.: Lézeres felületkezelés és modellezés. EME, Cluj-Napoca, 2007. https://eda.eme.ro/handle/10598/8923

[5] Bagyinszki Gy., Bitay E.: Nagy energiasürüségü eljárások hegeszthetőségi szempontjai. In: Fiatal műszakiak tudományos ülésszaka XVII., Cluj-Napoca, Romania, Múszaki Tudományos Füzetek, 2012. 13-18.

https://eda.eme.ro/handle/10598/15489 